\title{
Analysis of Financial Performance Using Budget Absorption Indicators
}

\author{
Safriansah $^{1}$, Nizwan Zukhri' ${ }^{2}$, Andriyansah ${ }^{3}$ \\ ${ }^{1}$ Postgraduate Program, Universitas Terbuka, Indonesia \\ ${ }^{2}$ Faculty of Economics and Business, Universitas Bangka Belitung, Indonesia \\ ${ }^{3}$ Faculty of Economics and Business, Universitas Terbuka, Indonesia \\ safri_ansah@yahoo.com
}

\begin{abstract}
Budget absorption is one indicator in measuring the performance of the state revenue and expenditure budget. Most of the budget realization occurred in the fourth quarter. The absorption of the budget, especially expenditure on goods and services, has a significant effect in driving economic growth. The research objective was to analyze the effect of budget planning, budget execution, government internal control systems on budget absorption, financial performance at the "Forest Area Consolidation Hall in Sumatra Region with budget absorption as a mediating relationship. This research uses descriptive quantitative method. The number of samples in this study were 215 respondents. The sampling technique in this research is saturated sampling. The research results show that there is an effect of budget planning, budget execution and government internal control systems on budget absorption at the Forest Area Consolidation Center in Sumatra Region. In addition, budget absorption also affects financial performance at the Forest Area Consolidation Center in Sumatra Region. Budget Absorption Mediates the Relationship between Budget Planning and Financial Performance at the Forest Area Consolidation Center in Sumatra Region. Absorption of Budget Mediates the Relationship between Budget Implementation and Financial Performance at the Forest Area Consolidation Center in Sumatra Region. Absorption of Budget Mediates the Relationship between the Government's Internal Control System and Financial Performance at the Forest Area Consolidation Center in Sumatra Region.
\end{abstract}

Keywords

budget absorption, internal control system financial performance

\section{Introduction}

Budget absorption is one indicator in measuring the performance of the state revenue and expenditure budget. Quality state spending is the realization of state spending which is carried out on time. According to Setyawan (2016), work units are still experiencing delays in disbursing state expenditures and still show a tendency to accumulate disbursement of state expenditures at the end of the year. Most of the budget realization occurred in the fourth quarter. Some researchers have found a phenomenon, namely the realization of state spending is not carried out on time. What happens in the field shows that at the beginning of the fiscal year, the realization of central government spending tends to be low, but at the end of the fiscal year it has actually increased rapidly. The absorption of the budget, especially expenditure on goods and services, has a significant effect in driving economic 
growth. For this reason, every government agency must regulate its expenditure so that it runs smoothly and can support the successful achievement of national development targets (Kasmad R, et al., 2019). Budget absorption is not required to reach one hundred percent, but it is hoped that budget absorption is able to meet at least more than eighty percent of the stipulated budget.

According to Herriyanto (2012) from researching the research literature, accumulated payments in the fourth quarter reflect budget absorption that is not in accordance with the activity plan that has been previously determined. The level of absorption of the budget can affect financial performance or budget realization in either category. The spending patterns of ministries and institutions have not undergone significant changes, so the importance of this research is to look at the phenomena that occur in the 7 (seven) work units of the Sumatra Regional Forest Area Stabilization Agency covering Medan, Palembang, Tanjung Pinang, Pangkalpinang, Banda Aceh, Pekanbaru, and Bandar Lampung, which is currently under the spotlight by the public, especially the performance of government agencies whose activities are sourced from the state budget. This is in accordance with research conducted by Priagung (2016); Julfirdana (2017) states that budget absorption has an effect on financial performance.

Budget absorption in this study is influenced by budget planning, budget execution and budget internal control system, if budget planning can be carried out properly and correctly in accordance with existing regulations, then budget absorption will be achieved well, otherwise poor budget planning will reduce its achievement. poor absorption of the budget. The good and bad of budget planning can affect the level of budget absorption. This is in accordance with research conducted by (Sari et al., 2019), (Ramdhani et al., 2017), (Sinaga, 2016), (Iqbal, 2018), (Zulaikah et al., 2018), they state that budget planning has an effect on budget absorption.

Budget execution is a factor that can affect budget absorption. Budget execution is a stage of budget management as a stage after the budget planning process is complete. The budget execution involves more people than the preparation and takes into account the feedback from real experience. The budget execution system must ensure adherence to budget authority and have the ability to carry out supervision and reporting that can immediately detect budget execution problems and provide flexibility for leadership. The budget implementation stage is related to the accountability aspect. If the budget execution stage has been supported by a good accounting and management control system, it is hoped that budget execution will not encounter many problems. Budget execution that is carried out properly and correctly according to budget planning can affect the level of budget absorption. This is in accordance with research conducted by Ramdhani et al., (2017); Zulaikah et al., (2018) stated that budget implementation has an effect on budget absorption.

Another factor that can affect budget absorption is the Government Internal Control System (SPIP). Hindriani et al., (2012); Zahra, F et al., (2020) the government internal control system refers to elements of the internal control system that have been practiced in government circles in various countries which include the control environment, risk assessment, control activities, information and communication as well as internal control monitoring. A quality budget does not necessarily guarantee success in achieving the goals and objectives that have been set if a plan has little chance of being successful if no control is exercised.

Properly implemented government internal control and in accordance with existing regulations can affect the level of budget absorption. This is in accordance with research conducted by Aldina (2016) which states that the government's internal control system 
affects budget absorption. Based on the description of the background of the problem, the researcher can formulate the research problem as follows:

1. Does the budget planning affect the absorption of the budget at the "Forest Area Consolidation Center in Sumatra Region?"

2. Does the implementation of the budget affect the absorption of the budget at the "Forest Area Consolidation Center in Sumatra Region?"

3. Does the government's internal control system affect the absorption of the budget at the "Forest Area Consolidation Center in Sumatra Region?"

4. Does the absorption of the budget affect the financial performance of the "Forest Area Consolidation Center in Sumatra Region?"

5. Can budget absorption mediate the relationship between budget planning and financial performance at the "Forest Area Consolidation Center in Sumatra Region?"

6. Can budget absorption mediate the relationship between budget execution and financial performance at the "Forest Area Consolidation Center in Sumatra Region?"

7. Can budget absorption mediate the relationship between the government's internal control system and financial performance at the "Forest Area Consolidation Center in Sumatra Region?"

\subsection{Theoretical Framework}

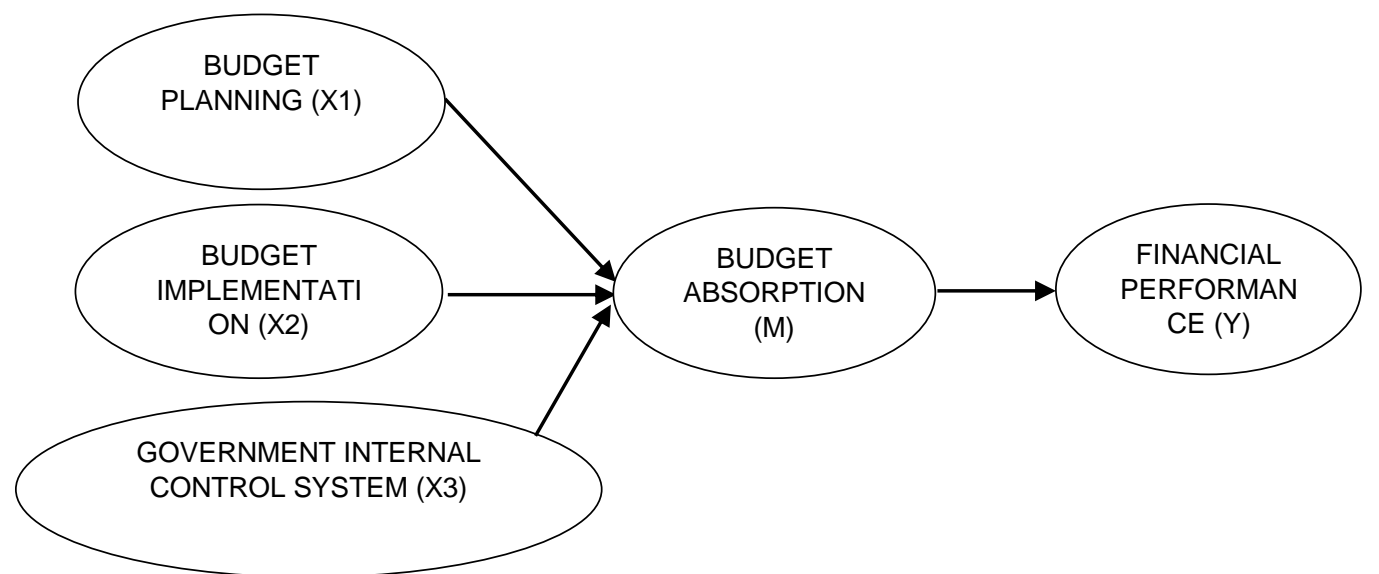

Figure 1. Research Model

Source: processed by researcher, 2020

\subsection{Hypotheses}

Based on the formulation of the problem in this study, the researcher can formulate the following hypothesis:

1. Budget planning affects budget absorption at the Forest Area Consolidation Center in Sumatra Region.

2. Budget implementation affects budget absorption at the Forest Area Consolidation Center in Sumatra Region.

3. The government's internal control system affects budget absorption at the Forest Area Consolidation Center in Sumatra Region.

4. Budget absorption affects financial performance at the Forest Area Consolidation Center in Sumatra Region.

5. Budget absorption can mediate the relationship between budget planning and financial performance at the Forest Area Consolidation Center in Sumatra Region.

6. Budget absorption can mediate the relationship between budget execution and financial performance at the Forest Area Consolidation Center in Sumatra Region. 
7. Budget absorption can mediate the relationship between the government's internal control system and financial performance at the Forest Area Consolidation Center in Sumatra Region.

\section{Research Methods}

This research uses descriptive quantitative method. The approach in this research provides a systematic, factual and accurate description of the causal relationship of budget planning, budget execution, and the government's internal control system on budget absorption and the relationship between budget absorption and financial performance. While the number of samples in this study were 215 (two hundred and fifteen) respondents. The sampling technique in this research is saturated sampling. The development of this research instrument is by distributing questionnaires to employees of the BalaiPemantapan Kawasan Hutan in Sumatra, covering 7 (seven) regions, namely: Medan, Palembang, Tanjung Pinang, Pangkalpinang, Banda Aceh, Pekanbaru, and Bandar Lampung using research instruments such as questionnaires distributed via online link.

The questionnaire is a list of questions that have been formulated previously from the development of indicators with a Likert scale of 1-5. While the data source in this study used primary data and secondary data. The method of quantitative data analysis in this study uses path analysis. The relationship between variables is indicated by a number of path coefficients ( $\rho \mathrm{ij}$ ), where this coefficient is equivalent to the standardized beta coefficient (ß). This technique allows the assessment of direct and indirect effects.

\section{Results and Discussion}

\subsection{Respondents Characteristic}

Based on the test results, it is known that the gender of the respondents is mostly male at 54\%. The age characteristics of most respondents were over 40-50 years old (34\%), respondents were more than 30-40 years old (27\%), aged less than 30 years $(21 \%)$ and over 50 years old by $18 \%$. The characteristics of the working period of the majority of respondents with a working period of more than 10-15 years (34\%), the work period of the respondents above 5-10 years (27\%), a working period of more than 15 years $(21 \%)$ and a work period of less than 5 years was $18 \%$. The educational characteristics of the largest respondents were Diploma education at 39\%, respondents with a Bachelor degree (S1) by $34 \%$, respondents with a SMA / SMK education at 16\%, and Master's education (S2) by $11 \%$.

\subsection{Descriptive Statistics}

Tabel 1. Descriptive Statistic

\begin{tabular}{|l|r|r|r|r|r|}
\hline & N & Minimum & Maximum & Mean & Standar Deviation \\
\hline Perencanaan Anggaran & 215 & 14 & 29 & 23.00 & 3.602 \\
Pelaksanaan Anggaran & 215 & 9 & 20 & 15.18 & 2.545 \\
Sistem Pengendalian & 215 & 11 & 24 & 18.73 & 2.928 \\
Penyerapan Anggaran & 215 & 14 & 29 & 23.01 & 3.948 \\
Kinerja Keuangan & 215 & 11 & 25 & 19.30 & 3.358 \\
Valid N (listwise) & 215 & & & & \\
\hline
\end{tabular}

Source: processed from primary source, 2020 
Based on table 1, it is known that the budget planning variable has a minimum value of 14 and a maximum of 29 with an average value (mean) of 23.00 and a standard deviation of 3.602. The budget execution variable has a minimum value of 9 and a maximum of 20 with an average (mean) value of 15,18 and a standard deviation of 2.545. The government internal control system variable has a minimum value of 11 and a maximum of 24 with an average (mean) value of 18.73 and a standard deviation of 2.928 . The budget absorption variable has a minimum value of 14 and a maximum of 29 with an average (mean) value of 23.01 and a standard deviation of 3.948. The financial performance variable has a minimum value of 11 and a maximum of 25 with an average (mean) value of 19.30 and a standard deviation of 3.358.

\subsection{Data Validity Testing}

The criterion is if $r$ count is greater than $r$ table means valid, on the other hand, if $r$ count is less than $r$ table it means invalid. Based on the level of confidence (degree of freedom) chosen was $95 \%$ and d.f $=5 \%$ with a total sample of 215 respondents obtained $r$ table of 0.133 . The results of validity testing can be seen in the corrected item-total correlation column, it is known that the results of calculating the validity of all research questionnaire items for the budget planning variable are greater than the $r_{\text {table }}$ of 0.133 . It can be concluded that the questionnaire items are all valid, this means that the research indicators can be used as data collection tools to measure budget planning variables. The results of the validity test can be seen in the corrected item-total correlation column. It is known that the results of calculating the validity of all questionnaire items of the research variable of budget implementation are greater than rtabel of 0.133 . It can be concluded that the questionnaire items are all valid, this means that the research indicators can be used as a means of collecting data to measure budget execution variables.

The results of the validity test can be seen in the corrected item-total correlation column. It is known that the results of calculating the validity of all questionnaire items of the government internal control system variable are greater than $r$ table of 0.133 . It can be concluded, that the questionnaire items are all valid, this means that the research indicators can be used as a means of collecting data to measure the variables of the government's internal control system.

The results of the validity test can be seen in the corrected item-total correlation column. It is known that the results of calculating the validity of all items of the research questionnaire, the budget absorption variable, is greater than the $r$ table of 0.133 . It can be concluded that the questionnaire items are all valid, this means that the research indicators can be used as a means of collecting data to measure the budget absorption variable.

The results of the validity test can be seen in the corrected item-total correlation column. It is known that the results of the validity calculation for all research questionnaire items for the financial performance variable are greater than the $r$ table of 0.166 . It can be concluded that the questionnaire items are all valid, this means that the research indicators can be used as a data collection tool to measure financial performance variables.

\section{Reliability Testing}

Reliability testing to determine the value of the instrument used to collect primary data from the research sample is reliable or unreliable. Reliable shows the measuring instrument used can be relied on from time to time. Testing with criteria if $r$ count $<0.60$ means not reliable and if $r$ count $>0.60$ means reliable. The reliability test of the budget planning variable obtained a value of 0.804 . The value of 0.804 is greater than the test number 0.60 , so the reliability test results on the budget planning variable can be declared 
reliable or reliable. The interpretation of the results of the reliability test means that the research indicators used as measurement tools can be relied on to measure the budget planning variables.

The reliability test of the budget implementation variable obtained a value of 0.751 . The value of 0.751 is greater than the test number 0.60 , so the reliability test results on the budget execution variable can be declared reliable or reliable. The interpretation of the results of the reliability test means that the research indicators used as measurement tools can be relied on to measure the variable of budget execution. The reliability test of the government internal control system variable obtained a value of 0.729 . The value of 0.729 is greater than the test number 0.60 , so the reliability test results on the government internal control system variable can be declared reliable or reliable. The interpretation of the results of the reliability test means that the research indicators used as measurement tools can be relied on to measure the variables of the government's internal control system.

The reliability test of the budget absorption variable obtained a value of 0.809 , the value of 0.809 was greater than the test number 0.60 , then the reliability test results on the budget absorption variable could be declared reliable or reliable. The interpretation of the results of the reliability test means that the research indicators used as measuring instruments can be relied on to measure the budget absorption variable. Reliability test of financial performance variables obtained a value of 0.800 . The value of 0.800 is greater than the test number 0.60 , so the reliability test results on the financial performance variable can be declared reliable or reliable. The interpretation of the reliability test results means that the research indicators used as measuring instruments can be relied on to measure financial performance variables.

\subsection{Classic Assumption Test}

a. Normaility Test

Table 2. Kolmogorov-Smirnov Test

\begin{tabular}{|ll|r|}
\hline & & \multicolumn{1}{|c|}{ Unstandardized Residual } \\
\hline $\mathrm{N}$ & & 215 \\
Normal Parameters ${ }^{\mathrm{a}, \mathrm{b}}$ & Mean & .0000000 \\
& Std. Deviation & 1.81039294 \\
Most Extreme Differences & Absolute & .055 \\
\cline { 2 - 3 } & Positive & .026 \\
& Negative & -.055 \\
Kolmogorov-Smirnov Z & & .800 \\
Asymp. Sig. (2-tailed) & & .545 \\
\hline
\end{tabular}

a. Test.distribution is normal

b. Calculated from data

Source: processed from primary data, 2020

The results of testing with the Kolmogorov-Smirnov method show that the unstandarized residual value in Asym. Sig. (2-tailed) is greater than 0.05. This means that all the data tested are normally distributed and suitable for use in further research. 
Tabel 3. Multicollinearity Test using VIF

\begin{tabular}{|ll|r|r|}
\hline \multirow{2}{*}{ Model } & \multicolumn{2}{|c|}{ Collinearity Statistics } \\
\cline { 3 - 4 } & \multicolumn{1}{|c|}{ Tolerance } & \multicolumn{1}{c|}{ VIF } \\
\hline 1 & Budget Planning & .315 & 3.174 \\
& Budget Implementation & .334 & 2.995 \\
& Control System & .419 & 2.389 \\
& Budget Absorption & .452 & 2.214 \\
\hline
\end{tabular}

a. Dependent Variable: Financial Performace

Source: processed from primary data, 2020

Based on the results of the analysis test, it can be seen whether or not there is a multicollinearity problem in the variables studied. The basis for decision making used is the amount of VIF (Variance Inflation Factor) and tolerance in which the guidelines for a regression model that is free from multicollinearity meet the criteria of having a VIF value below 10 and having a tolerance number above 0.10 . In the coefficient section, you can see the three independent variables, the VIF number is below $10(\mathrm{X} 1=3.174, \mathrm{X} 2=2.995, \mathrm{X} 3$ $=2.389$, and $\mathrm{M}=2,214)$. Likewise, the tolerance value is above $0.10(\mathrm{X} 1=0.315, \mathrm{X} 2=$ 0.334 , Y $1 \mathrm{X} 3=0.419$ and $\mathrm{M}=0.452$ ). Thus, it can be concluded that the regression model does not have multicollinearity problems in the VIF magnitude.

\section{c. Heteroscedasticity Test}

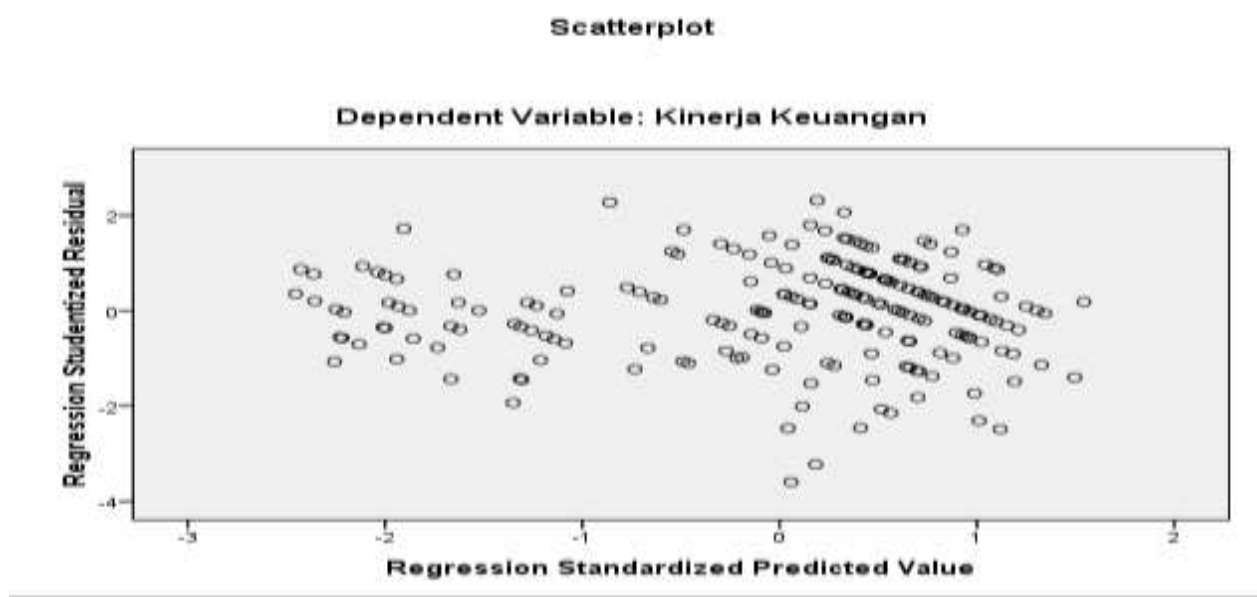

Figure 2. Heteroscedasticity Test

Source: processed from primary data, 2020

Based on the results of the analysis test, it shows that the dots spread randomly, do not form a clear, specific pattern, and are spread either above or below the number 0 on the $\mathrm{Y}$ axis.This means that there is no heteroscedasticity in the regression model, so the regression model is feasible. used to predict financial performance variables $(\mathrm{Y})$ based on the input of budget planning variables $\left(\mathrm{X}_{1}\right)$, budget execution $\left(\mathrm{X}_{2}\right)$, government internal control system $\left(\mathrm{X}_{3}\right)$ and budget absorption $(\mathrm{M})$. 


\section{d. Autocorrelation Test}

Table 4. Autocorrelation test of $X_{1}, X_{2}, X_{3}, M$ and $Y$

\begin{tabular}{|l|lr|}
\hline Model & \multicolumn{2}{|c|}{ Durbin-Watson } \\
\hline 1 & & $1.461^{\mathrm{a}}$ \\
\hline
\end{tabular}

a. Predictors: (Constant), Budget Absorption, Government Internal Control System, Budget Implementation, Budget Planning,

b. Dependent Variable: Financial Performance

Source: processed from primary data, 2020

Based on the calculation results, it can be seen that the Durbin-Watson (DW) value is 1.461. Because the Durbin-Watson (DW) value is between -2 to +2 , there is no autocorrelation. Thus, it can be concluded that the regression model above does not occur autocorrelation.

\section{Path Analysis}

Path analysis is divided into two sub-structures, the first substructure analyzes the effect of budget planning, budget execution and government internal control systems as exogenous variables on budget absorption as endogenous variables. The second substructure analyzes the effect of budget planning, budget execution, government internal control systems and budget absorption as exogenous variables on financial performance as endogenous variables.

Table 5. The Effect of Testing Results on Exogenous and Endogenous

\begin{tabular}{|l|c|c|c|}
\hline Influencing Variable & Estimation & Probability & Description \\
\hline Endogen: Budget Absorption \\
\hline Budget Planning & 0,300 & 0,000 & Significant \\
\hline Budget Implementation & 0,242 & 0,002 & Significant \\
\hline $\begin{array}{l}\text { Government Internal } \\
\text { Control System }\end{array}$ & 0,276 & 0,000 & Significant \\
\hline Endogen: Financial Performance & & \\
\hline Budget Planning & 0,146 & 0,028 & Significant \\
\hline Budget Implementation & 0,221 & 0,001 & Significant \\
\hline $\begin{array}{l}\text { Government Internal } \\
\text { Control System }\end{array}$ & 0,140 & 0,016 & Significant \\
\hline Budget Absorption & 0,443 & 0,000 & Significant \\
\hline
\end{tabular}

Source: processed from primary source, 2020

\subsection{Calculation of Direct, Indirect and Total Effects}

The results of these calculations, all coefficients between variables can be depicted in the path diagram in Figure 3: 


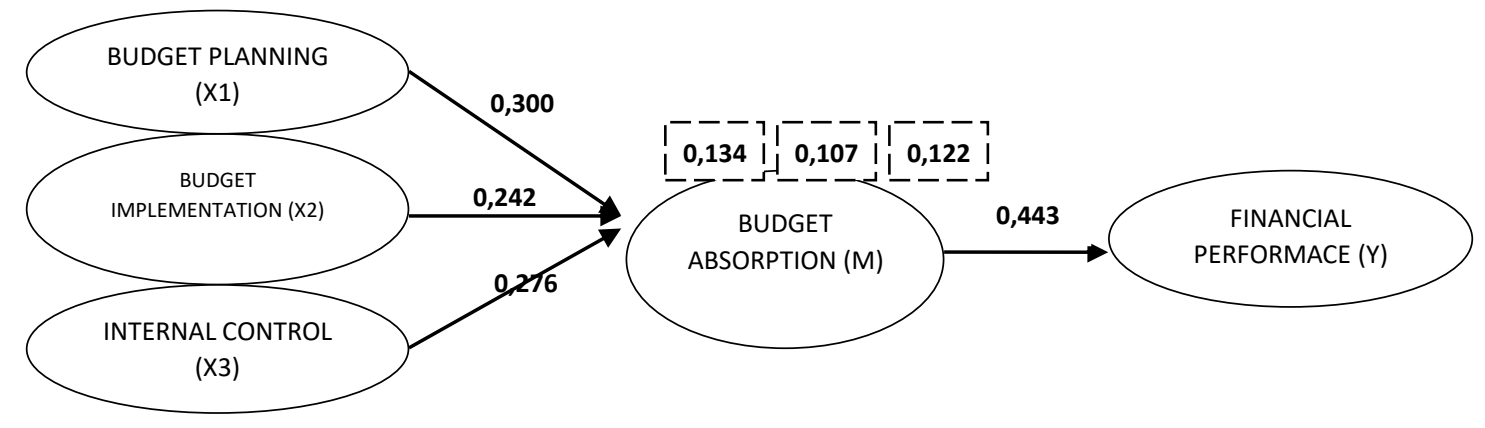

Figure 3. Result of Path Analysis Calculation

Structural Equation:

Substructure 1: $M=0,300 X_{1}+0,242 X_{2}+0,276 X_{3}+\varepsilon_{1}$

Substructure 2: $\mathrm{Y}=0,146 \mathrm{X}_{1}+0,221 \mathrm{X}_{2}+0,140 \mathrm{X}_{3}+0,443 \mathrm{M}+\varepsilon_{2}$

\subsection{Discussion}

Based on the research results and descriptions, the following will be discussed about:

1. Effect of budget planning on budget absorption.

Based on the test results, it was obtained a budget planning of 0.300 with a significant value of $0.000<0.05$. This shows that budget planning has a significant effect on budget absorption at the Sumatra Forest Area Consolidation Center. Based on the results of the report (Directorate General of Fiscal Balance, 2010), the size of the absorption rate of regional spending in funding public services is strongly influenced by the budget planning process. If budget planning can be carried out properly and correctly in accordance with existing regulations, then budget absorption will be achieved properly. Conversely, poor budget planning will reduce the achievement of poor budget absorption. The good and bad of budget planning can affect the level of budget absorption. The results of this study support research conducted by (Sari et al., 2019), (Ramdhani et al., 2017), (Sinaga, 2016), (Iqbal, 2018), (Zulaikah et al., 2018) stated that budget planning affect budget absorption.

\section{Effect of budget execution on budget absorption.}

Based on the test results, it was found that the budget implementation was 0.242 with a significant value of $0.002<0.05$. This shows that budget execution has a significant effect on budget absorption at the Sumatra Forest Area Consolidation Center. The budget execution process includes matters within the work unit's internal, as well as the payment mechanism process (budget disbursement). The linkage of the budget to the absorption of the budget, namely implementation is the activity of efforts carried out to realize all plans and policies that have been formulated and stipulated. The budget execution system must ensure adherence to budget authority and have the ability to carry out supervision and reporting that can immediately detect budget execution problems and provide flexibility for leadership. The budget implementation stage is related to the accountability aspect. If the budget execution stage has been supported by a good accounting and management control system, it is hoped that budget execution will not encounter many problems. Budget execution that is carried out properly and correctly according to budget planning can affect the level of budget absorption. The results of this study support the research conducted by (Ramdhani et al., 2017), (Zulaikah et al., 2018) which states that budget implementation has an effect on budget absorption. 
3. The influence of the government's internal control system on budget absorption.

Based on the test results, it was found that the government internal control system was 0.276 with a significant value of $0.000<0.05$. This shows that the government's internal control system has a significant effect on budget absorption at the Forest Area Consolidation Center for Sumatra Region. Quality budgets do not necessarily guarantee success in achieving the goals and targets that have been set if a plan has a low probability of success if control is not implemented. . According to (Mardiasmo, 2001) there are three main aspects that can support the success of achieving the goals and objectives in the budget, namely supervision, control and inspection. Government internal control that is implemented properly and in accordance with existing regulations can affect the level of budget absorption. The results of this study support the research conducted by (Aldina, 2016) which states that the government's internal control system affects budget absorption.

\section{Effect of budget absorption on financial performance.}

Based on the test results, it was obtained that the absorption of the budget was 0.443 with a significant value of $0.000<0.05$. This shows that the absorption of the budget has a significant effect on financial performance at the BalaiPemapanatan Kawasan Hutan for Sumatra Region. Budget absorption is related to the use of the budget for a public program. Through the use of the budget, the government uses it for infrastructure development as well as facilities and infrastructure needed by the government. The more budget absorption that is realized for development can increase the growth in financial performance because the more development there is, the more regional revenues will increase, thus affecting the increase in financial performance. The sub-optimal absorption of the budget indicates problems in financial management. Absorption of the budget, particularly spending on goods and services, has a significant effect in driving economic growth. For this reason, each government agency must regulate its expenditure so that it runs smoothly and can support the successful achievement of national development targets. However, budget absorption is not required to reach $100 \%$ (one hundred percent), but budget absorption is expected to be able to meet at least more than $80 \%$ (eighty percent) of the stipulated budget. According to (Herriyanto, 2012) from the research literature search, the accumulation of payments in the fourth quarter reflects the absorption of the budget that is not in accordance with the activity plan that has been previously determined. The level of absorption of the budget can affect financial performance or budget realization in either category. The results of this study support the research conducted by (Priagung, 2016), (Julfirdana, 2017), which states that budget absorption has an effect on financial performance.

5. Budget absorption mediates the relationship between budget planning and financial performance

Based on the test results, it is found that the direct absorption budget planning is 0.300 and the budget absorption on financial performance is 0.443 , so that the value of $0.300 \times 0.433=0.134$ is obtained. This means that budget absorption can mediate the influence between budget planning and financial performance. A good budget planning process can affect budget absorption and financial performance, but budget planning without the support of good budget absorption cannot improve financial performance. Conversely, budget planning with good budget absorption can improve financial performance. Good budget absorption can mediate the relationship between budget planning and financial performance. 
6. Budget absorption mediates the relationship between budget execution and financial performance

Based on the test results, it is found that the implementation of the budget for direct absorption is 0.242 and the absorption of the budget for financial performance is 0.443 , so that the value of $0.242 \times 0.433=0.107$ is obtained. This means that budget execution can mediate the influence between budget execution and financial performance. The budget execution process includes issues within the work unit's internal, as well as the payment mechanism process (budget disbursement). The linkage of the budget to the absorption of the budget, namely implementation is the activity of efforts carried out to realize all plans and policies that have been formulated and stipulated. Good budget execution affects the absorption of the budget properly so that it will also affect financial performance. It can be concluded indirectly that good budget absorption can mediate the relationship between budget execution and financial performance.

7. Budget absorption mediates the relationship between the government's internal control system and financial performance

Based on the test results, it was found that the government's internal control system for direct absorption was 0.276 and budget absorption on financial performance was 0.443 , so that the value of $0.276 \times 0.433=0.122$ was obtained. This means that budget execution can mediate the influence between budget execution and financial performance. Proper supervision of budget planning and implementation can increase budget absorption and simultaneously improve financial performance. Research conducted by (Aldina, 2016) shows that the government's internal control system has a significant positive effect on budget absorption, while research conducted by (Kawedar et al., 2019) shows that the government's internal control system as measured by the control environment, activities control, information and communication, and monitoring controls have a positive and significant effect on financial performance.

\section{Conclusion}

Based on the results of research and discussion, the following conclusions can be drawn:

1. There is an influence of budget planning on budget absorption at the Forest Area Consolidation Center in Sumatra Region.

2. There is an effect of budget implementation on budget absorption at the Forest Area Consolidation Center in Sumatra Region.

3. There is an influence of the government's internal control system on budget absorption at the Forest Area Consolidation Center in Sumatra Region.

4. There is an effect of budget absorption on financial performance at the Forest Area Consolidation Center in Sumatra Region.

5. Budget absorption mediates the relationship between budget planning and financial performance at the Forest Area Consolidation Center in Sumatra Region.

6. Budget absorption mediates the relationship between budget execution and financial performance at the Forest Area Consolidation Center in Sumatra Region.

7. Budget absorption mediates the relationship between the government's internal control system and financial performance at the Forest Area Consolidation Center in Sumatra Region. 


\section{References}

Aldina. (2016). Pengaruh Kualtas DIPA, Sistem Pengendalian Internal Pemerintah dan Sistem Anggaran Berbasis Kinerja terhadap Tingkat Penyerapan Anggaran.

Direktorat Jenderal Perimbangan Keuangan. (2010). Direktorat Jenderal Perimbangan Keuangan. Grand Design Desentralisasi Fiskal,[Pdf](Http://Www. Djpk. Kemenkeu. Go. Id/Info-Utama/203-Grand-Designdesentralisasi-Fiskal).

Herriyanto, H. (2012). Faktor-Faktor yang Mempengaruhi Keterlambatan Penyerapan Anggaran Belanja pada Satuan Kerja Kementerian/Lembaga di Wilayah Jakarta. Tesis, Universitas Indonesia, Jakarta.

Hindriani, N., Hanafi, I., \& Domai, T. (2012). Sistem Pengendalian Intern Pemerintah (SPIP) Dalam Perencanaan dan Pelaksanaan Anggaran di Daerah (Studi Pada Dinas Kesehatan Kabupaten Madiun). Wacana: Jurnal Sosial Dan Humaniora, 15(3), 1-9.

Iqbal. (2018). the Effect of Budget Planning and Human Resource Competence on Budget Absorption.

Julfirdana. (2017). Proses Perencanaan Kebijakan Anggaran dan Dampaknya terhadap Kinerja pada Kantor Kementerian Agama Kabupaten Karimun.

Kawedar, W., . S., Handayani, R. S., \& Purwanto, A. (2019). Good Governance, Sistem Pengendalian Internal, Dan Kinerja Keuangan Organisasi Sektor Publik. Matrik: Jurnal Manajemen, Strategi Bisnis Dan Kewirausahaan, 13(2), 214. https://doi.org/10.24843/matrik:jmbk.2019.v13.i02.p09

Priagung. (2016). Pengaruh Penyerapan Anggaran , Budaya Organisasi , Kepuasan Kerja Dan Pengawasan Inspektorat Terhadap Kinerja Keuangan Organisasi Publik ( Studi pada Pemerintah Daerah Kabupaten Banjarnegara ). 2(1), 1-15.

Ramdhani et al. (2017). Pengaruh Perencanaan Anggaran, Kualitas Sumber Daya Manusia dan Pelaksanaan Anggaran terhadap Penyerapan Anggaran pada Organisasi Perangkat Daerah Provinsi Banten. Riset Akuntansi Terpadu, 10(1), 134-148.

Kasmad, Rulinawaty et al. (2019) The unwise policy of community based-organisation: Can it empower them? implementation network of food diversification in indonesia. Opcion 35(Special Issue 22), pp. 2899-2921

Sari, L. G. E., Yuesti, A., Sudja, I. N., \& Kepramareni, P. (2019). Analysis of Budget Planning, Competence of Human Resources and Implementation of the Viii Lldikti Region Budget with Organizational Commitment as A Moderation. International Journal of Contemporary Research and Review, 10(02), 21273-21288. https://doi.org/10.15520/ijcrr.v10i02.655

Setyawan, A. (2016). Analisis Keterlambatan Penyerapan Anggaran Belanja Satuan Kerja Kementerian/Lembaga di Wilayah Pembayaran KPPN Bojonegoro Tahun Anggaran 2015. June, 4-13.

Sinaga. (2016). Analisis Rendahnya Penyerapan Anggaran Kementerian/Lembaga (K/L) dan Pemerintah Daerah. 4, 449-467.

Zulaikah et al. (2018). Faktor-Faktor yang Mempengaruhi Penumpukan Penyerapan Anggaran pada Triwulan IV di Kota Cimahi. 1221-1234.

Zahra, F., Parwati, N. M. S., Pakawaru, M. I., Wachyudi, D., \& Zahara, Z. (2020). How Does Organizational Factors Influence The Assimilation Of Knowledge Management And E-Learning Functions At The State University?. Journal of Critical Reviews, 7(12), 1219-1224. 